\title{
Ways to Improve Road Safety Audit in the Republic of Kazakhstan
}

\author{
K. Ibrayev'), D. Kapskiy ${ }^{2)}$, S. Bogdanovich ${ }^{3)}$ \\ ${ }^{1)}$ GOLD PRODUCTS LLP (Nur-Sultan, Republic of Kazakhstan), \\ ${ }^{2)}$ Belarusian National Technical University (Minsk, Republic of Belarus), \\ ${ }^{3)}$ Belarusian Road Scientific-Research Institute "BeldorNII" (Minsk, Republic of Belarus) \\ (C) Белорусский национальный технический университет, 2021 \\ Belarusian National Technical University, 2021
}

\begin{abstract}
There are two types of internationally recognized engineering approaches to addressing road safety issues - proactive and reactive. Predicted or proactive approach includes prevention of accidents and taking corrective measures before accidents can occur. One example of this approach is road safety audit, which is a relatively new tool in developing countries. The paper has analyzed approaches to road safety audit outlined in guidelines of the United Kingdom, Ireland, USA, Australia, Canada, as well as in guidelines of Asian Development Bank for the countries of Central Asian Regional Economic Cooperation. All reviewed documents are characterized by a similar approach to the basic definitions, to selection of audit team and requirements for team members, to the main stages of road safety audit. All reviewed guidelines emphasize that audit is not a means of project works evaluation, verification of compliance with standards, a means of projects ranking or evaluation. Approach to road safety audit, outlined in recommendations developed in the Republic of Kazakhstan has also been analyzed. It has been established that the document does not meet approaches adopted in developed countries. Conditions of the Republic of Kazakhstan require development of a new document based on analysis of the best international experience. Currently, the Republic of Kazakhstan has embarked on a gradual introduction of "road forgiving mistakes" approach to the design and operation of roads. This fact should also be considered when revising road safety audit manual.
\end{abstract}

Keywords: road safety, road safety audit, Republic of Kazakhstan, goals of road safety audit, audit methodology

For citation: Ibrayev K., Kapskiy D., Bogdanovich S. (2021) Ways to Improve Road Safety Audit in the Republic of Kazakhstan. Science and Technique, 20 (1), 45-51. https://doi.org/10.21122/2227-1031-2021-20-1-45-51

\section{Пути повышения качества аудита безопасности дорожного движения в Республике Казахстан}

\author{
Асп. К. Ибраев ${ }^{1)}$, докт. техн. наук, доц. Д. Капский²), канд. техн. наук, доц. С. Богданович \\ ${ }^{1)}$ Компания «Голд Продактс» (Нур-Султан, Республика Казахстан), \\ ${ }^{2)}$ Белорусский национальный технический университет (Минск, Республика Беларусь), \\ ${ }^{3)}$ Белорусский дорожный научно-исследовательский институт «БелдорНИИ» (Минск, \\ Республика Беларусь)
}

Реферат. Существуют два типа международно признанных инженерных подходов к решению проблем безопасности дорожного движения - упреждающий и реактивный. Прогнозируемый, или упреждающий, подход включает предотвращение аварий и принятие корректирующих мер до того, как они могут произойти. Одним из примеров такого подхода является аудит безопасности дорожного движения. Это относительно новый инструмент в развивающихся странах. В статье проанализированы подходы к аудиту безопасности дорожного движения, изложенные в руководствах Великобритании, Ирландии, США, Австралии, Канады, а также в рекомендациях Азиатского банка развития для

\author{
Адрес для переписки \\ Ибраев Кензат \\ Компания «Голд Продактс» \\ ул. Туркестан, 30/224, \\ 010000, г. Нур-Султан, Республика Казахстан \\ Тел.: +7 $701614-42-40$ \\ goldproducts.kz@gmail.com
}

\author{
Address for correspondence \\ Ibrayev Kenzat \\ GOLD PRODUCTS LLP \\ 30/224, Turkistan str., \\ 010000, Nur-Sultan, Republic of Kazakhstan \\ Tel.: +7 $701614-42-40$ \\ goldproducts.kz@gmail.com
}


стран Центральноазиатского регионального экономического сотрудничества. Для всех рассмотренных документов характерен схожий подход к основным определениям, выбору аудиторской группы и требованиям к ее членам, основным этапам аудита безопасности дорожного движения. Во всех рассмотренных руководствах подчеркивается, что аудит - это не средство оценки работ по проекту, проверки соответствия стандартам, средство ранжирования или оценки проектов. Также был проанализирован подход к аудиту безопасности дорожного движения, изложенный в рекомендациях, разработанных в Республике Казахстан. Установлено, что документ не соответствует подходам, принятым в развитых странах. Условия Республики Казахстан требуют разработки нового документа, основанного на анализе лучшего международного опыта. В настоящее время Республика Казахстан приступила к постепенному внедрению концепции «прощающей ошибки дороги» в проектировании и эксплуатации дорог. Этот факт также следует учитывать при пересмотре руководства по аудиту безопасности дорожного движения.

Ключевые слова: безопасность дорожного движения, аудит безопасности дорожного движения, Республика Казахстан, цели аудита безопасности дорожного движения, методология аудита

Для цитирования: Ибраев, К. Пути повышения качества аудита безопасности дорожного движения в Республике Казахстан / К. Ибраев, Д. Капский, С. Богданович // Наука и техника. 2021. Т. 20, № 1. C. 45-51. https://doi.org/10. 21122/2227-1031-2021-20-1-45-51

\section{Introduction}

Currently, the role of traffic management quality improvement has increased. Works to improve road safety require further improvement in order to reduce total socio-economic losses in road traffic.

In all documents, developed and under development, such as Plan of Priority Actions for Road Safety increase in the Republic of Kazakhstan for 2017-2020, developed with support of Asian Development Bank, "National Concept for Road Safety" project, developed by Interdepartmental Research Institute, Academy of Law Enforcement Agencies under the General Prosecutor's Office of the Republic of Kazakhstan, as well as by other international financial institutions: World Bank, EBRD, as well as TRACECA, it is noted that at present there is a gap in regulatory and technical base in the field of road safety in terms of taking into account interconnection of elements affecting road safety: people, road infrastructure and transport, as well as absence of such a preventive tool in this system as a road safety audit.

As international experience shows, remaining within the framework of engineering activity traditional for the Republic of Kazakhstan, which reduces mainly to maintenance of a considerable length of roads, it will be difficult to significantly improve traffic safety. Based on the analysis of the world practice of road safety provision, the country should begin work on introduction of modern technologies and methods of work organization in this direction. This primarily relates to road safety audits.
Road safety is a global socio-economic issue. In developing countries, the number of victims and fatalities in road traffic accidents is growing at an alarming rate. From economic point of view, the cost of road traffic accidents is estimated at about one percent $(1.0 \%)$ of gross national product in low-income countries, one and a half percent $(1.5 \%)$ in middle-income countries, and two percent (2.0\%). in high-income countries [1]. According to the World Health Organization [2], road traffic injuries will take third place in 2020 among all causes in terms of losing a year of life, considering possible disability, compared with the ninth place in 1990. Road Safety Manual indicates that thirty-four percent $(34.0 \%)$ of all accidents occurred partially or completely due to road traffic factors [3].

There are two types of internationally recognized engineering approaches to addressing road safety issues - proactive and reactive. In the case of reactive approach, measures to improve safety are taken after the accident has already occurred. In many developing countries, use of reactive approach does not bring significant success due to the lack of regulatory requirements necessary to use this approach [4]. Predicted or proactive approach includes prevention of accidents and taking corrective measures before accidents can occur. One example of this approach is road safety audit (RSA, Road safety audit), which is a relatively new tool in developing countries. In essence, audit is an accident prevention tool. Studies that have attempted to quantify the benefits of audit have produced impressive results. In the UK, road administration estimated benefit-cost ratio for RSA 
to be $15: 1$, in New Zealand this ratio is estimated to be 20:1. Cost-benefit analysis in Denmark that passed safety audit showed an average profit margin of 146 percent in the first year [5].

The first road safety audits were carried out in the UK in the 1980s, and in Australia and New Zealand in the early 90s. However, until 1996, audits in many developed countries, including the USA, were not conducted. During the 1990s, audit was introduced in other countries such as Denmark, Canada, the Netherlands, Germany, Switzerland, Sweden and South Africa. Subsequently, RSA was actively introduced in developing countries such as Malaysia, Singapore, Bangladesh, India, Mozambique and the United Arab Emirates. Currently, the World Bank and the European Council for Transportation Safety are actively promoting their national road safety programs [6]. In a number of countries, RSAs are practiced in accordance with the guidelines of individual countries (their own guidelines). As early as 2008, the European Union adopted mandatory Directive 2008/96/EC "Road Infrastructure Safety Management" (hereinafter the "Directive"). The directive became law on November 19, 2008 and entered into force on December 19, 2010. The document introduced requirements and obliged the EU member states to introduce and carry out the following activities on the roads included in the network of trans-European transport corridors [7]:

- road safety audit;

- certification of road safety auditors;

- assessment of the impact on road safety of road construction and repair projects;

- traffic safety inspection;

- road network safety rating;

- informing the public about accident centers.

Actions of EU countries to implement the Directive have allowed member countries to achieve notable success in reduction of the accident rate. In 2010-2016, the number of deaths due to road accidents in the EU countries decreased by $19 \%$. In 2016, 25620 people died on EU roads, which is 510 less than in 2015 and 5900 less than in 2010. The total number of deaths per 10 thou- sand cars in all EU countries is 0.88. For comparison: in the Republic of Belarus this indicator is 1.48 people, and in the Republic of Kazakhstan -4.6 people [8].

In recent years, deaths due to road accidents in the EU countries have remained at approximately the same level. In response to this slowdown, revision of the Directive and adoption of a new version, which will be significantly expanded, are currently being prepared.

Currently, road safety audits are already used very widely: in all EU countries, the USA, Canada, Australia, New Zealand, and many developing countries. Normative documents on audit conduction in the Republic of Kazakhstan [9], Russia [10], Belarus [11] were developed and put into effect.

The purpose of this study is to compare guidelines for road safety audits in selected developed countries, with the goal of improving approaches to road safety in the Republic of Kazakhstan.

\section{Approaches to road safety audit in developed countries}

In modern conditions of globalization and development of information technology, obtaining information has been greatly simplified. When developing or substantially revising a normativetechnical document, studying experience of other countries is not only desirable, but also necessary. This avoids potential errors and reduces costs. Moreover, it is important to use as samples such documents that, firstly, do not have theoretical errors, and secondly, have a positive experience in their use. We reviewed approaches to road safety audit in some developed countries.

The review included road safety audit guidelines used in the UK [12], Ireland [13], the USA [6, 14], Australia [15], Canada [16], as well as Asian Development Bank guidelines for countries of Central Asian Regional Economic Cooperation (CAREC) [17].

All of these documents are available for review on the Internet. The first factor considered was definition of road safety audit. The results are shown in Tab. 1. 
Definition of audit in the reviewed documents

\begin{tabular}{|l|l|}
\hline \multicolumn{1}{|c|}{ Country } & \multicolumn{1}{|c|}{ Definition } \\
\hline United Kingdom & $\begin{array}{l}\text { Road safety audit is an independent and formal assessment of road project during design and at the } \\
\text { end of construction (preferably before the road is open for traffic) }\end{array}$ \\
\hline Ireland & $\begin{array}{l}\text { Road safety audit is an assessment of the road during design and construction before the road is put } \\
\text { into operation, to identify potential safety hazards that can affect any road user, to propose measures } \\
\text { to eliminate or mitigate these problems }\end{array}$ \\
\hline USA & $\begin{array}{l}\text { Road safety audit is a formal safety audit of an existing or future road or intersection by an indepen- } \\
\text { dent audit team. RSA team considers safety of all road users, qualitatively evaluates and reports on } \\
\text { road safety problems and opportunities for improving safety }\end{array}$ \\
\hline Australia & $\begin{array}{l}\text { Road safety audit is an official audit of a future road project or traffic organization or existing road, } \\
\text { during which an independent qualified team reports on potential project problems that affect safety } \\
\text { performance. Road safety audit process addresses safety of all road users }\end{array}$ \\
\hline Canada & $\begin{array}{l}\text { Road safety audit is a formal and independent audit of road project effectiveness, carried out by expe- } \\
\text { rienced team of safety experts and covering safety issues for all road users }\end{array}$ \\
\hline Asian Development Bank & $\begin{array}{l}\text { Road safety audit is a formal and detailed study of a road project by independent and competent group } \\
\text { of auditors, the result of which is a report with a list of potential safety problems in the project }\end{array}$ \\
\hline
\end{tabular}

The essential points that distinguish most definitions, are that audit:

- is a formal procedure;

- is performed by an independent team of specialists:

- identifies potential security issues in the project.

A characteristic feature of most of the documents examined was that they contain indication of what road safety audit is not.

Thus, all documents expressly emphasize that audit is not a verification of project's compliance with standards or best practices, it is an examination task. Audit is not a check of conformance of a finished road to the project. In addition, audit does not consider safety of individual structures.

A separate emphasis on the fact that audit is not a check for compliance with applicable standards is due to many factors, including:

- too much confidence in national standards, without determining whether these standards are actually suitable for safety;

- standards often contain only minimal requirements. Application of several such standards with minimum requirements may lead to a decrease in overall safety of the facility;

- standards usually cover the most general situations, and not all possible ones;

- in some projects, norms that do not correspond to this type of road may be used;

- outdated or inappropriate national norms and standards may be mistakenly used;
- sometimes a combination of various elements in project development can lead to a result that is not the best in terms of security;

- often the designer is pressured to reduce estimated cost of the facility, which can be implemented primarily at the expense of security considerations;

- sometimes changes are made during construction that do not take into account operational safety factors.

The next step examined the objectives of road safety audit. The following audit objectives are indicated in reviewed documents (Tab. 2).

You may notice that the common goal in all the documents reviewed is to identify potential problems with road safety.

Recommendations regarding stages of road safety audit in the documents reviewed are somewhat different. In a generalized form, six stages can be distinguished during planning, design and construction of a road project, at which road safety audit can be carried out. They correspond to generally accepted phases in planning, design, construction, operation and maintenance of roads:

- stage of feasibility study;

- stage of development of project documentation;

- stage of development of working documentation;

- stage of road construction;

- pre-operational stage;

- existing road (road safety inspection). 
The objectives of road safety audit in reviewed documents

\begin{tabular}{|l|l|}
\hline \multicolumn{1}{|c|}{ Country } & \multicolumn{1}{|c|}{ Audit objective } \\
\hline United Kingdom & $\begin{array}{l}\text { Identify potential road safety problems that may affect any road users and propose measures to ad- } \\
\text { dress or mitigate these problems }\end{array}$ \\
\hline Ireland & $\begin{array}{l}\text { Identify potential safety hazards that could affect any road user to propose measures to address or } \\
\text { mitigate these problems }\end{array}$ \\
\hline USA & $\begin{array}{l}\text { RSA objective is to answer the following questions: } \\
\text { What elements of the road can pose a safety problem: to what extent, for which road users, and un- } \\
\text { der what circumstances? } \\
\text { What options are there to address or mitigate identified security issues? }\end{array}$ \\
\hline Australia & The objective of road safety audit is to identify any existing project safety deficiencies \\
\hline Canada & $\begin{array}{l}\text { The objective of road safety audit: } \\
\text { minimize frequency and severity of possible accidents; } \\
\text { consider safety of all road users, including vulnerable road users; } \\
\text { make sure that all possible measures have been taken to mitigate consequences of road accidents; } \\
\text { minimize potentially negative impacts on safety on designed road and on adjacent roads }\end{array}$ \\
\hline Asian Development Bank & $\begin{array}{l}\text { To minimize the risk of accidents, and to minimize severity of any accidents that may occur at a new } \\
\text { road facility }\end{array}$ \\
\hline
\end{tabular}

Usually, the earlier the audit is conducted during planning and design process, the easier and cheaper effective changes are achieved that increase the level of security [17].

\section{Existing approach to road safety audit in the Republic of Kazakhstan and directions for its improvement}

Document R RK 218-142-2017 "Recommendations on audit and inspection of road safety on public roads" [9] is in force in the Republic of Kazakhstan.

The following definition is given in the document: "Road safety audit: verification of organizations activities results during design, construction and operation of roads for compliance with current requirements of regulatory and technical documents on organization and safety of traffic".

At the same time, Directive on road infrastructure safety management No 96/2008, European Parliament and Council, Brussels, 2008 is indicated as a source of determination.

However, this source does not contain the above definition. Definition in the European Directive is as follows: "Road safety audit means an independent detailed systematic and technical safety check relating to the design characteristics of a road infrastructure project and covering all stages from planning to early operation".

Thus, original source does not say anything about checking for compliance with current requirements of regulatory and technical documents. This approach led to a critical methodological error, as a result of which the document, to a large part, develops provisions that are not related to road safety audits.

As for the audit objectives, they are not explicitly indicated in the document, what significantly complicates the work.

The criteria at which the audit is carried out in accordance with R RK 218-142-2017 do not meet and completely contradict international practice. According to the document, the basis for the audit on public roads are the following:

- receipt of well-grounded complaints and proposals from legal entities or individuals that contain information about violations of requirements for ensuring road safety by road organizations or the public;

- significant changes in organization of traffic, etc.; 
- contractual obligations between the Customer and the contractor as a separate form of audit services, and as part of design, technical supervision, as well as diagnostics and certification of roads.

This approach means that the audit is a random procedure, is not mandatory and is not systematic. Conduction of the audit as a response to complaints has no precedent in the world and deprives the procedure authority.

Final results that are expected are not relevant to road safety audit. In accordance with [9], the results of roads audit are used with the following purpose:

- to assess the degree of conformity of technical level indicators, operational condition and maintenance level of roads and road structures with established standards, based on requirements for ensuring traffic safety;

- to rank a local site, road or network by degree of risk of road safety;

- to assess effectiveness of appointment of repair measures on acceptable values of weighted average total accident rate;

- to assess economic efficiency of measures to improve traffic safety;

- to assess the results of activities of road organizations to reduce the level of road accidents and manage "hazardous areas" of roads;

- to establish factors and conditions conducive to occurrence of accidents and areas of their concentration;

- to justify measures for organization and safety of road traffic in the planning of road works and formation of targeted programs to improve road safety.

The above-mentioned tasks in themselves are important enough to improve road safety, however, none of the tasks are solved within the framework of road safety audit in classic appreciation of the term.

Based on the analysis of [9], it can be said that the term "road safety diagnostics" is the most appropriate term for the activity described in the document. Given theoretical errors in [9], development of a new regulatory and technical document is an acceptable way to correct the situation.

Based on the analysis already performed, it can be noted that in developed countries there is a similar approach to the basic definitions, to selection of audit team and to the requirements for team members, to the main stages of road safety audit. There are some differences in approaches to the stages of the road life cycle, which is explained by peculiarities of national legislation in the field of construction and terminology used.

Road safety audit, being a formal standardized procedure, involves implementation of certain actions. These actions can be summarized as follows: making a decision on the need for audit, selection of audit team, exchanging information before audit conduction, checking drawings and documents in office conditions, driving of audit team on the road in the daytime and at night, preparing of audit report, discussion of audit report with the project team, writing of a response report by the project team. A separate stage, which is adjacent to road safety audit, but may not be considered directly as audit, is monitoring of road safety after putting the road into operation, which is carried out at differrent times: after a year, 3 years, sometimes more.

Experienced engineers with education and experience in the field of organization and safety of traffic, road design are involved in the audit. An important requirement is continuous improvement of theoretical and practical training of auditors in specialized courses. The audit team includes at least 2 people, one of whom is the team leader.

Currently, the Republic of Kazakhstan has embarked on a gradual introduction of "road forgiving mistakes" approach to the design and operation of roads. This fact should also be considered when revising road safety audit manual. There are examples of such a specialized approach to audit in the world. For example, in audit manual, which operates in Australia and, especially, in New Zealand [18], all requirements and recommendations are set out in accordance with implementation of Safe System concept, which is actively implemented in these countries.

\section{CONCLUSIONS}

1. Approaches to road safety audit in developed countries are similar. In most cases, when determining an audit, it is emphasized that the audit is 
a formal procedure, performed by independent team of specialists, and also identifies potential security problems in the project.

2. Characteristic feature of RSA manuals in developed countries is that they provide an indication of what a road safety audit is not. All documents expressly emphasize that an audit is not a verification of a project's compliance with standards or best practices.

3. Approach to road safety audit currently adopted in the Republic of Kazakhstan contains critical methodological errors, as a result of which the document, to a large part, develops provisions that are not related to road safety audit.

4. An acceptable way to remedy the situation is to develop a new regulatory and technical document.

\section{REFERENCES}

1. Jacobs G., Aeron-Thomas A., Astrop A. (2000) Estimating Global Road Fatalities. Crowthorne, Transport Research Laboratory, TRL Report, No 445.

2. World Health Organization and the World Bank (2004) World Report on Road Traffic Injury Prevention. Geneva.

3. American Association of State Highway and Transportation Officials (2010) Highway Safety Manual. $1^{\text {st }} \mathrm{ed}$. Washington, DC.

4. Roads and Highways Department (RHD), Ministry of Communication, Bangladesh (May 2005) Guidelines for Road Safety Audit. Dhaka.

5. Institute of Transportation Engineers (ITE), U. S. Department of Transportation, Federal Highway Administration. Road Safety Audits: an Emerging and Effective Tool for Improved Safety. Available at: www.ite.org/technical/In tersectionSafety/RSA.pdf. (Accessed 3 July 2013).

6. Transportation Research Board (2003) National Cooperative Highway Research Program. NCHRP Synthesis 321. Road Safety Tools for Local Agencies: a Synthesis of Highway Practice. Washington, DC.
7. European Directive on Road Safety Management [2008/96/EC]. Guidelines for Competent Authorities on the Application of the Directive. London: Department for Transport, 2011. Available at: https://www.gov.uk/govern ment/uploads/system/uploads/attachment_data/file/3565/g uidelines.pdf. (Accessed 6 August 2018).

8. Kapskii D. V., Bogdanovich S. V. (2018) Ways and Means for Road Infrastructore Safety Improvement in Several Codntries of the Customs Union. Avtomobil'nye Dorogi i Mosty $=$ Roads and Bridges, (2), 95-102 (in Russian).

9. R RK 218-142-2017 Recommendations on the Audit and Inspection of Road Safety on Public Roads. Available at: https://online.zakon.kz/Document/?doc_id=39278623\#pos $=0 ; 0$ (in Russian).

10. ODM 218.6.027-2017 Recommendations for Road Safety Audit in Design, Construction and Operation of Roads. Available at: http://docs.cntd.ru/document/456090610 (in Russian).

11. TKP [Technical Code of Common Practice] 590-2016 Roads. Requirements for Inspection of Road Safety System. Available at: https://rovar.info/tkp-590-2016-avtomobilnye-dorogitrebovanija-k-obsledovaniju-sistemy-obespechenija-bdd.

12. Institution of Highways and Transportation (November, 2017) HD 19/15 Guidelines for Road Safety Audit.

13. Transport Infrastructure Ireland (2017) Standard NRA HA 19 Road Safety Audit Guidelines. Dublin.

14. US Department of Transportation (2006) FHWA Road Safety Audit Guidelines. Washington, DC.

15. Guide to Road Safety. Part 6: Road Safety Audit. No AGRS06-09. Austroads Publication, 2009.

16. Ho G., Zein S., de Leur P. (2001) The Canadian Road Safety Audit Guide. Ottawa, Transportation Association of Canada. 81.

17. CAREC Road Safety Engineering Manual 1: Road Safety Audit. Asian Development Bank, 2018. http://doi.org/10. 22617/TIM179172-2.

18. NZ Transport Agency (2013) Road Safety Audit Procedures for Projects. Wellington. Available at: https://nzta. govt.nz/assets/resources/road-safety-audit-procedures/docs/ road-safety-audit-procedures-tfm9.pdf.

Received: 08.10.2019

Accepted: 10.12 .2019

Published online: 29.01.2021 